\title{
INVINCIBLE KITSCH OR As TOURISTS IN THE AgE OF Des Alwi
}

\author{
Tsuchiya Kenji and James Siegel
}

The Banda Islands lie about 1,500 miles from Jakarta, more or less the same distance from the Indonesian capital as Bangkok. The main town on the islands, Bandaneira, is set on an island, Neira (sometimes Naira), only a few kilometers from end to end. Across its harbor is an almost perfect cone, the volcanic mountain Gunung Api, whose slopes enter the sea with only the slightest flange at their base. Less than 700 meters in height, its dwarf size and its perfect shape make it seem more an emblem of a volcano than a mountain whose eruptions have caused disaster. A third, longer island, Lontor or Banda Besar, wraps itself around the back of Neira. Entering the harbor, the harbor mouths disappear into the folds formed by Gunung Api and Lontor; one seems to find oneself on a lake. The clarity of the waters, the profusion of coral and multicolored fish, the ease with which the fish are obtained, the self sufficiency of these remote islands, which even during the difficulties of the Japanese occupation are said not to have experienced hunger; all this makes one feel that utopia is rightly set on a distant island.

The authors spent February 20th through February 24th, 1988 as tourists on Banda. This account is based on what we were told there unless, of course, we cite other sources. ${ }^{1}$

Aside from a few officials and tourists, the population of Banda is divided into two: Bandanese (Orang Banda) and Butungese (Orang Butung). The latter came to Banda at the end of the nineteenth century from the Butung Islands to the east of Sulawesi, new migrants arriving sporadically until the present. Butungese speak their own language (Bahasa Butung) as well as Indonesian and Bandanese. It is said on Banda that the original Bandanese were eliminated by the Dutch; it is also said that they fled to the island of Ei (sometimes $\mathrm{Ai}$ ), one of the remoter islands in the Banda group; others deny that the inhabitants of Ei are descendants of the original Bandanese. Still others claim that the original Bandanese were not eliminated but were integrated into the present Orang Banda. In any case, the present Bandanese are of mixed descent, including people claiming European, Chinese, and Arabic

1 The major English source on Banda is Willard Hanna, Indonesian Banda: Colonialism and Its Aftermath in the Nutmeg Islands (n.d., n.p. [privately printed by Des Alwi and available in his museum on Banda Neira]). We owe the title, "Invincible Kitsch" to B. R. O'G. Anderson. 
ancestry as well as from many Moluccan and Sulawesi groups. Bahasa Banda, the Bandanese language, differs from Indonesian in only a handful of words. "Sama dengan Bahasa Indonesia," "the same as Indonesian," we were told. The Bandanese are thus a new group based not on descent but on place of birth and use of a language barely different from the national language.

Mixed descent is apparent in the faces of the Bandanese. One finds European, Chinese, and Arab physiognomies. There is frank acknowledgement of such extraction, but descent does not mark cultural differences; one does not find those with Arabic names, for instance, eating Arabic food, wearing articles of Middle Eastern clothing, or trying in any way to indicate descent. In any case, descent seems usually mixed and those called "Badilla," one of the Arabic families on Banda, sometimes look Javanese and, in fact, one might find that they have Javanese ancestors. Why ancestry remains in memory when it does not seem to have social functions is an unanswered question.

It remains to be explained also how and why a new group, so lacking in common traits, evolved when the alternative of using descent was always open and when, for the last forty years, Bandanese could have simply called themselves "Indonesian." It also remains to be explained why the Orang Butung, who fit the criteria for being Orang Banda, being born there and speaking Bandanese, are excluded from the category.

Banda Neira is filled with Dutch residences dating from the nineteenth century, many of them mansions with pillars and verandas. These probably date from after 1864 when there was great prosperity as a result of a monopoly of nutmeg cultivation. The narrow roads that run between these buildings, with their low fences, not a meter in height, are sometimes so overgrown as to be mere paths. There are only a few motor vehicles on the island. Consequently there is a satisfying silence that is usually broken only by the loud sounds of Indonesian pop music emanating from some of the antique mansions or from one of the ships that arrive once or twice a week and, to attract passengers, broadcast music from loudspeakers during their entire stay. Indeed, one soon realizes that what one sees and thinks one remembers on Banda, the sense of tempo doeloe or "the old days" that comes through the eye and is magnified by one's own wishfulness, runs at odds with the life that occurs there.

Current Bandanese society is still not Indonesian metropolitan society, manners and outlook more closely approximating those of villages. For instance, the white foreigner misses the shouts of "hallo mister" that every Jakartan adolescent seems to come out with as he passes. The equivalent for Japanese, "Ajinomoto," after the packaged monosodium glutimate, and "Yamaha," after the motorbike, were altogether absent. Only preschool children or those in the first years of elementary school shout "hallo mister." Unlike their adolescent counterparts in cities, they do not allow the foreigner to pass by. Like village children, they cluster in groups and accompany the visitor.

One former resident of Banda, Des Alwi, now living in Jakarta, is responsible for restoring much of Banda Neira, for revitalizing certain Bandanese ceremonies, and for making other improvements. He is, for instance, said to be behind the building of Banda's small airfield and it is believed by Bandanese that he wants to repave the roads and to restore the

${ }^{2}$ Some words identified as Bandanese seem to be Malay. Here is a short list of words claimed to be exclusively Bandanese: "bétah" meaning "saya"; "pané" meaning "kamu"; "kerada" meaning "tidak." Bandanese also contains old forms derived from European languages; thus, "capayo" for "hat" from the Portuguese "chapéu" presumably. Sentence structure resembles Melayu rendah, the Malay spoken as a lingua franca in the nineteenth century. For example, "Dia orang punya berat 65 kilo." 
seventeenth century Fort Belgica. When we met him in Jakarta he told us that, on his mother's side, he is related to the Badillas, one of the two Arabic families on Banda. His father was from Ternate, where his grandfather was a religious advisor to the Sultan of Ternate before the family moved back to Palembang. He has Chinese as well as Arabic and Buginese ancestry. His father and uncle were sent to Banda from Palembang to learn to become captains of pearl-fishing boats. They married sisters from the Badilla family. This sort of detail about family history seems common amongst the Orang Banda. It does not conflict with a sense of being Bandanese even when, as with Des Alwi, most of the family history takes place elsewhere.

Des Alwi has taken the Badilla mansion in Banda and used part of it for a "museum" holding relics of Banda's past and paintings he has commissioned showing scenes of its history. The rest of the mansion is a hotel for tourists. Des Alwi's interest in finding a certain truth of Bandanese history is entangled with an interest in tourism, as we shall see. We do not mean to imply that his first concern is profit. He is a successful contractor and producer of films and has been engaged in other businesses both in Jakarta and Kuala Lumpur. He has built two more hotels on Neira's harbor. He is certainly Banda's major employer; his name seems unavoidable in conversations about Banda. But it is probable that his investment is a loss, the number of tourists being quite limited judging by the register which the hotel manager proudly offered to us for our inspection. His interest in tourism has to be seen in conjunction with his interest in history; we will come back to this important topic.

Before World War II Banda was the place of exile for some significant nationalist figures, including Mohammad Hatta, Sutan Sjahrir, Dr. Tjipto Mangoenkoesoemo, and Iwa Kusuma Sumantri. Des Alwi's museum contains a "Taman Baca Oom Hatta" [Uncle Hatta's Reading Garden], a room once used by Hatta as a study during his exile. It is now a small library containing mainly contemporary school books on Indonesian history. Hatta's house has been restored. Des Alwi himself restored the magnificent house of Sutan Sjahrir whose time of exile coincided with Hatta's. When they left for Java with the arrival of the Japanese, they took some of the Badilla children with them. Des Alwi followed soon after, though he was barely a teenager. In Jakarta he is known as the "anak angkat," the adopted child, of Sjahrir. According to his own account, after the war he studied audio communications in London and worked on the side as a newspaperman. He then joined the Indonesian diplomatic service. He worked in the Indonesian Embassy in the Philippines which he left during the PRRI/Permesta revolt, coming eventually to Malaysia where he knew Tun Abdul Razak. He was in business there and, he says, along with Benny Moerdani, presently General Benny Moerdani, Minister of Defense, was instrumental in helping to end Konfrontasi, the Indonesian policy of opposition to Malaysia. From the time of the arrival of the Japanese till the early 1960s when he returned to Indonesia, he did not see Banda. It was on his return that he began his project of developing the islands which economically were in a sad condition, their famous nutmeg production having fallen to a fraction of its former levels.

Des Alwi hopes to bring Banda once more into national and international view. He has a notion of what tourists want. Thus it is said on Banda that he is planning a fourth hotel, also on the harbor. As Banda has no sand, sand will be brought in to make a beach so it will look, said one of his employees, "like Bali." Bringing Banda into view can thus mean obscuring it through a notion of "pembangunan" or "development." One sees this too through the figure of a Bandanese whom Des Alwi put through the English Faculty of a university in Jakarta and who now acts as a tour guide and translator. The guide is careful to point out the coral, the possibilities of snorkeling, but not the Butungese villages along the shore nor, for 
instance, the sacred graves on Neira. The guide loyally follows the tourist brochure published by Des Alwi whose photos show no Butungese residences or magic-laden graves though it does have a picture of Des Alwi clutching a magnificent fish on its cover (see opposite).

Those within the realm of development are set off from others. On the far side of Gunung Api Des Alwi has had an enormous fish pond built, large enough, we were told, to hold a hundred different kinds of tropical fish. Alas, the number of fish was sadly reduced on our visit. This, said the guide, was the work of local people who come to the pond to fish, not understanding the importance of development and tourism. Others, however, point to the numerous turtles, and wonder; could they too have been hungry? "No," said the guide. He would hear no other explanation.

The point is not whether he is correct or not; it is the frustration he feels. He possesses knowledge, not technical but cultural. Banda's "tradisi" or "traditions" are best preserved by those who "mengerti," those who "understand" meaning not only those who know what those traditions are, but who also know their worth. As he uses the term, "understand" means "to be able to explain them [in English] to those from developed countries or from Jakarta, mainly tourists."

The guide sincerely wants to use his knowledge for the benefit of "Banda." He is outspoken about governmental neglect of the islands and about governmental corruption. But the local people do not understand him. A common enough experience. Here we see it at the point where a certain "Banda" is being constructed, one believed to be authentic; in keeping with Banda's history and natural setting. It is the point at which an image, justified by tourism itself, intervenes between visitor and place. It is in the interest of a certain international understanding that such an image is constructed. It was to us, tourists, that the guide made his complaint.

Des Alwi wants to recover Bandanese history and present it to the world. In his museum, one of his commissioned paintings, by Sofri Rino Hasan Basri, shows what Des Alwi considers the central fact of Bandanese history. The painting has a Dutchman on the left side, his rifle in hand, raised from his crotch and pointing at an angle to the sky. Facing him is a Japanese, naked except for a loincloth, holding a sword, also raised from his crotch and pointing at an angle to the sky. To those ignorant of Des Alwi's intention, the painting might seems to show the Dutchman and the Japanese in opposition. Such is not the case. At the feet of the Japanese are the beheaded, quartered remains of the Bandanese nobility. The painting commemorates the end of the Bandanese nobility in the seventeenth century, at the hands of a Dutch expedition strengthened by Japanese mercenaries.

For Des Alwi, this scene is the key to understanding Bandanese adat or customary ceremony. The chief ceremony is a dance drama called the cakalele, a term familiar in neighboring islands. Though performed for generations, even centuries, the meaning of the cakalele had been lost. But recently a document was recovered which shows that this drama contains, through a secret symbolism, the names of the slaughtered nobles. The Dutch had allowed the performance to continue because they were not aware of its meaning. They even had it performed for commemorations of their own. The Bandanese themselves had forgotten the meaning of the cakalele, though they continued to perform it, until the recovered document revealed its secret. And with that, Des Alwi arranged for its performance for tourists.

In Des Alwi's understanding, once one understands the cakalele, a great deal else follows. For instance: Banda contains several graves where people go to pray and seek benefits. One 


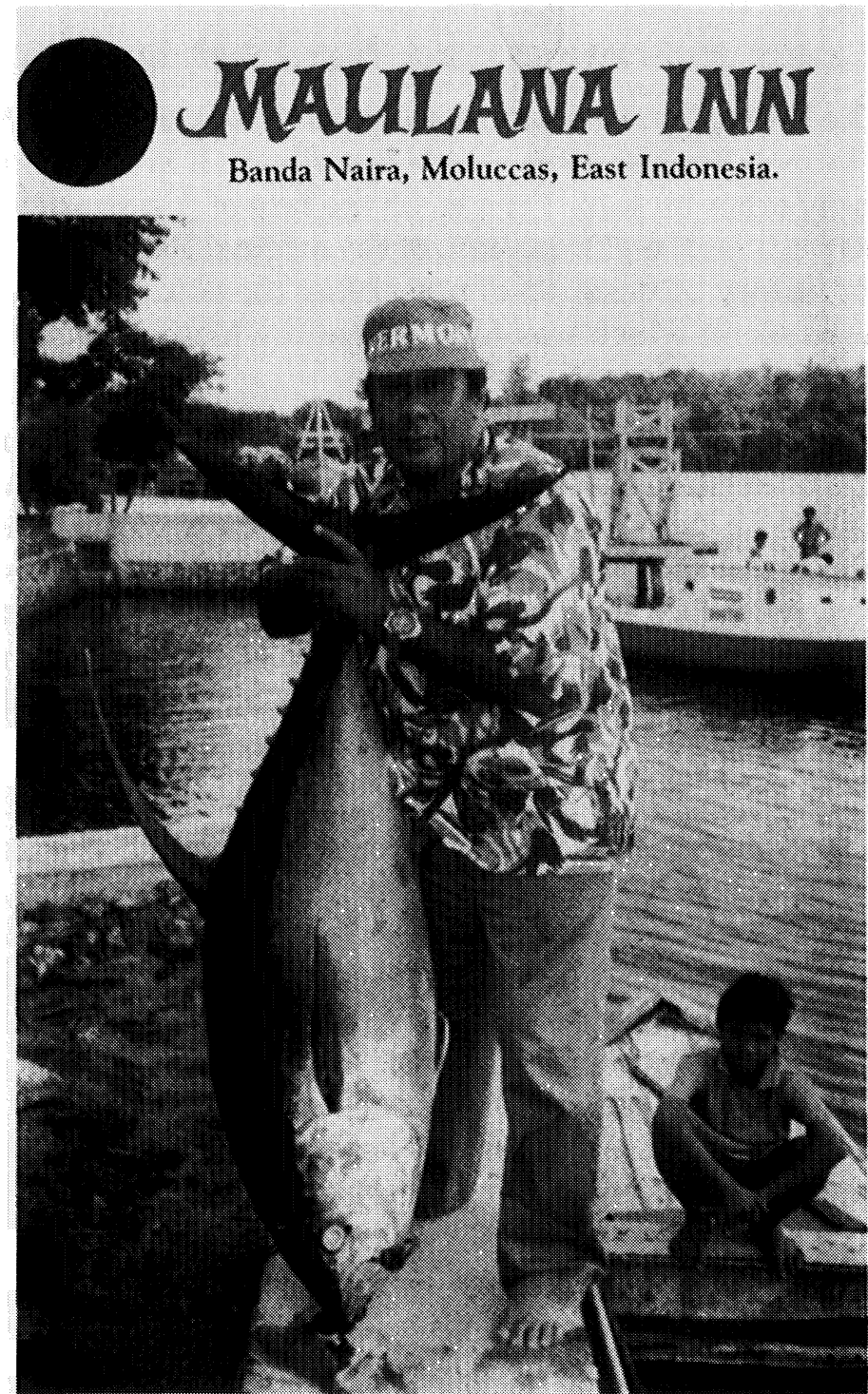

$I_{\mathrm{t}}$ is said that Christopher Colombus was searching for the SPICE ISLES of Banda-Naira and the Moluccas when he discovered America instead in 1492.

Portuguese Captain Antonio de Abreu, arrived in Banda in 1512, using a Malay pilot as guide. They were the first European strangers to come searching for the nutmeg. After subduing Malacca

ALBUQUERQUE sent hin with the first Portuguese squardon to the Moluccas to find the spice islands of Bandr-Naira. 
in particular, on Neira's mountain peak, Des Alwi believes to be the grave of one of the slaughtered noblemen. The cakalele begins with a visit to this grave and to others which Des Alwi believes to be the burial sites of other slaughtered nobles. Other Bandanese we spoke with were not aware of this interpretation. The recovery of such history animates Des Alwi.

"Des," as he is usually referred to, can speak at length on the slaughter of the nobles and can refer one to the Dutch sources which describe it. It is not too much to say that this fact overshadows any other for him. Yet it is, on the face of it, a strange fact to celebrate. It marks the defeat, and perhaps the elimination, of the original Bandanese. But, Des Alwi believes, it is a question of history. A question of preserving the names of those whom the Dutch eliminated. This is the secret which was forgotten and which was unearthed and broadcast with nationalism and independence.

It is, nonetheless, a commemoration of cruelty, bloodiness, dismemberment, and defeat, which might be understandable if it were a matter of being certain that valiant resistance or the wrong done to one's people was not forgotten. Yet, oddly, the picture emphasizes the Japanese mercenary at the expense of his Dutch employers or the resistance of the victims. And, in speaking with Des Alwi, we could find no trace of resentment against the Dutch or the Japanese, of that time or now, nor could we elicit any story of resistance by the Bandanese nobles. Nonetheless the tone he adopts as he speaks of Bandanese history is a mixture of excitement and pride and, especially, a determination to show the facts of history, coterminous with something called "Banda."

The rehabilitation of Banda, its "development," is founded on preservation of the physical effects of colonialism. But Des Alwi's pride is not, of course, in Dutch or Portuguese colonialism. Nor has he resurrected the Banda of his youth; one does not feel any nostalgia in him for his own past on Banda. His pride is not in the massacre, nor in the recovery of knowledge of the massacre; as he says, it is all in the Dutch sources. He is concerned, rather, with recovering and presenting the meaning of the cakalele. His project is comparable to that of astronomers who believe that the universe was created from an initial explosion, the evidence for which is cosmic dust. What was once mere dust is now evidence. Des Alwi insists on an initial catastrophic event; but the recovery of this event is also the cracking of the code of the cakalele. Or rather, focusing on this event lets one see that the cakalele really is a code; it actually contains information. It is not a series of gestures which Bandanese performed mindlessly for generations, even centuries.

To be effective as a code, the cakalele has, of course, to be performed. When the British and American ambassadors to Indonesia visited Banda, Des Alwi included their presence in a film he produced about the Bandanese boats called kora-kora. The voice over announces:

"The distinguished guests were also greeted by a Cakalele dance and by the elders and other village folk of the Banda Islands. The gift of a kapsete [a European-style helmet, of the type used in the seventeenth century] to the honored guests was the highest honor which could be conferred by the people of Banda, and made them honorary members of the Banda population." 3

The film shows the pleased but embarrassed ambassadors in the act of putting their gifts on their heads. The commentary continues, "The United States ambassador made a speech thanking the friendly Banda natives for their kindness and for making him an honorary citizen of Banda."

\footnotetext{
${ }^{3}$ We wish to thank Des Alwi for having shown us the film and for having furnished the typescript of the voiceover from which the quotation is taken.
} 
There is more about the ambassadors, though the film is ostensibly about the kora-kora boats. Yet the scene, reminiscent of the bestowing of Indian war head-dresses on American politicians, and so full of kitsch to a Japanese or a Westerner, is not senseless within the logic of Des Alwi. It is precisely in the eyes of tourists that the cakalele is validated. If it began in catastrophe and continued as meaningless repetition, today it is different. Today, it is meaningful; its meaning extending across the most distant cultural borders. What could not be made sense of, what could only be repeated, is now performed, and the performance is validated by tourists from, the movie points out, the exclusive tourist ship, "the Linblad [sic] Explorer" and by official representatives of powerful nations.

This, of course, is the point at which history becomes kitsch; becomes, that is, precisely forgettable. Kitsch is a cultural product that needs no conservation; rather the reverse. But it is disposed of in a certain place; it is not that history is not conserved, but that it is conserved in the minds of tourists, to whom it is passed along. Safe with strangers, one need no longer be worried by it.

The painting is reminiscent of comic-book drawings. According to Des Alwi, the painter is a comic-book artist when he has no other commissions. This urge to put history into easily transmittable form is perhaps for the purpose of putting it out of mind by transferring it to strangers who do not speak one's language. The perfect transferability of signs despite different languages stands as a correction to the centuries when the cakalele was repeated and neither its performers nor its audience understood it. That what it communicates is lurid and fearful is secondary to the relief that Des Alwi feels that it is sensible rather than merely repetitive.

That in colonial times the cakalele was performed for themselves by people who did not understand it is a source of shame to Des Alwi. He rids himself of it by insisting that all the while there was a code which now makes the motions of the performance transparent; anyone seeing it will understand it. The "anyone" is, of course, the tourist. "Anyone" can understand it by reference to universally effective signs which need no historical background, other than that provided by the explanation of the cakalele itself. Its reference is no longer specific experiences identified with by those who feel themselves descended from those who went through them. At this point, its fearful content is merely, like the painting, lurid. The recovery of the meaning of the cakalele and the draining off of its historical aura are nearly simultaneous acts.

Des Alwi's fascination with the cakalele stems from his feeling that he, via his identification of himself as an Orang Banda, has a past he was not aware of before. This is also the case with another Bandanese. Wilky Rinpassa was born in 1943 and is the customary chief for one section of Banda. He is the one who found the solution to the cakalele. After he was appointed adat chief, he came across a 12-page document of his great uncle, written in 1926, partly in Dutch, partly in Malay, which explained the cakalele symbolism.

Wilky Rinpassa's father had a Dutch education. "AMS [Algemeene Middelbare School or General Secondary School], the same as Suharto," he said. His father was an agricultural officer for the Dutch; he died shortly after Wilky was born. His mother sent him to the neighboring island of Ambon for junior high school; his uncle lived there. When the RMS (Republik Maluku Selatan) rebellion against the Indonesian central government broke out in 1950 his mother called him home. He later returned to Ambon to finish school; but his mother quarreled with his uncle and again summoned him home. He finished junior high school in Banda. No further schooling was available. He decided then to go to the local teacher's training school though it was the same level as junior high school. He began his 
practice teaching. He had not yet reached his full height. The school children ridiculed him, called him "child-teacher," so he quit. He became a fisherman. Then he was invited by his future father-in-law to work in his office. He was "overjoyed" and accepted. Eventually he went to work for the state plantation authority where he works today.

He regrets lost opportunity. Had he lived, his father, who had the same privileged education as President Suharto, might himself have advanced far, and certainly Wilky Rinpassa would have had more opportunities. Perhaps, though he did not say so, he might, like so many other Orang Banda, have left Banda. The story of having to leave school, missing opportunities for lack of money, is common in Indonesia. But seldom is it told today, as Wilky tells it, with a sense of regret; that is, with a sense of real possibilities left unfulfilled.

During the Japanese occupation, someone in Ambon accused Wilky's father of being a spy for the Allies. He was arrested and beaten. The trouble, Wilky said, arose because he was of Portuguese descent; his face looked European. The Japanese, for this reason, would not believe him. "If he confessed, he was beaten; if he did not confess, he was beaten." He died of his wounds after the Japanese released him.

Wilky is a defender of historical interpretation. He looks at Butung villages and sees that some of them have two mosques, some one, some none. This is the result of the Dutch policy of rewarding villages that supported them and punishing those that opposed them. But, he complained, people do not know of this.

Wilky feels a connection with his father, but it is not entirely a familial one. He said, quite rightly in our opinion, that he himself has a European face. However, he said he does not resemble his father but his mother. The resemblance he feels with his father is not because of his social descent from him. It is because of the circulation of European genes [he used the English word] in Banda, though Europeans and their culture, except for some artifacts, have vanished; a circulation which ran through both Wilky and his father. It is a fact of biology, not of family, in Wilky's thinking.

That European genes worked through both Wilky and his father is an accident. Divorced from cultural significance, the physiognomy produced by such genes simply emerged. But it is an accident through which Wilky discovered history. Wilky Rinpassa knows from the story of his father's death that signs can fail. His father's face meant one thing, his father's sentences another. The face Wilky has been given, like his name, which he said is a corruption of the Portuguese, is the result of the coming to Banda of people centuries ago. Aside from the name and the awareness it brings, nothing remains of Portuguese culture within his family. There is only the biological fact, the physiognomy that the Japanese misread. The "truth" of his father's face is that it meant "Portuguese" rather than "Dutch," that "Portuguese," in the context of Banda, refers to events so long ago that they are without significance today. The "truth" of his father's face is that it had no significance; he could as well have looked Javanese or Malay, for instance, since Wilky has only a certain percentage of Portuguese genes.

His father was the victim of two accidents: first, the emergence of his appearance, the emergence of an attribute which had lost its meaning; second, of having been misunderstood, really un-understood, by the Japanese. Wilky thus knows that there is accident; the merely accidental emergence of appearances. He sees the Japanese as having believed in appearance, hence having been deceived by chance and thus made brutally stupid. Wilky, himself also the embodiment of chance circulation, defends himself by interpreting. Thus he believes that there are objects today, for instance mosques, for instance the cakalele, that are in fact signs of something that happened previously. This is an act of interpretation he feels 
others do not make or make wrongly. Perhaps he himself would not make it if he did not feel that because of his father's face, because of his own face, he did not have to beware of objects which, though others are not aware of it, require interpretation. It is with this attitude that he uncovered the words of his great uncle, written a half century earlier, and so discovered that the cakalele contained secret signs. In this manner Wilky stabilizes the universe.

We can use the experience of Wilky Rinpassa to think about Des Alwi. Des Alwi's entrance onto the nationalist stage is also an accident and, in a certain way, an accident of descent. As we have said, he is known as the "adopted son" of Sutan Sjahrir, a famous nationalist and former prime minister. This, it might be said, is an accident of Banda's remoteness. The Dutch, putting nationalists in internal exile, chose remote places, amongst them Banda. Had Sjahrir not been exiled to Banda, he could not have become Des Alwi's father. Before Des Alwi is a nationalist by conviction he was one not by birth but by the accident of an adoption.

Safety, according to Wilky, lies in seeing that one is readable by others, the "others" being representatives of world history from amongst whom came the colonizers of yesterday and the tourists of today. Des Alwi saw in the code that Wilky discovered that he, Des Alwi, had a past he had not been aware of before. He, like Wilky, thus insists that he be readable, that his past be correctly knowable by the greater world. He thus prepares himself for once again being found by that world, reducing the accident of being found to a determined sense. A proper reading is a reading by the greater world, in that sense repeating the moment of being chosen but reducing the accident to a determined sense.

The "legibility" of Des Alwi and Wilky Rinpassa rests on similar stories. To the degree that Des Alwi insists he is a Bandanese and insists on promoting the cakalele, he identifies himself with the slaughtered Bandanese nobles. They, like Wilky's father, were the victims of blind power. Like Wilky's father, they were innocent. They should not have been victims. But, unlike Wilky's father, they were chosen because of their descent and social position. They were chosen because of who they were. And it is precisely this, who they were, their names, that the cakalele continued to present to generation after generation who could not understand this message. The discovery of the code of the cakalele proves that their names remain. Des Alwi's insistence on celebrating the cakalele means that these names are not senseless and that previous performances were not mindlessly repetitive.

Des Alwi, in promoting the cakalele, identified himself with those whose names announced themselves to the world after being obscured. The choice of himself, Des Alwi, by the man later to be Indonesia's prime minister during its struggle against the Dutch, could be believed to be the insistence of his own name and its readability, even as a child, its attachment to himself and its acknowledgment first by Sjahrir and then by other important figures. But to identify with the victims of a brutal power, one whose bloodiness Des Alwi frequently returned to in his conversations with us, is also good reason to want to drain away that bloodiness, to leave only its cartoon, as, nearly, in the picture, or its harmless image, as in the cakalele performed for the tourists of the Lindblad Explorer.

When Des Alwi returns to Banda, his "komplek," a series of buildings on the waterfront between two of his hotels where he stays, is always crowded, we were told. If someone is sick, if someone needs help, Des Alwi gives. "Rp.10,000, Rp.5,000, Rp.20,000," said Oskar, a Bandanese we shall introduce in a moment. "He is a president," a word Oskar uses interchangeably with "king." Des Alwi is a king because he is the chief employer and the chief 
furnisher of capital on Banda. But that alone would not suffice to enthrone him. He is a king because he gives in the way Oskar described. He is a king because he is a benefactor. Bandanese feel they have a right to ask him for help.

Des Alwi's kingship is validated, in the eyes of Bandanese, by his association with people in Jakarta. "He knows everyone important," we were told many times, usually in the same words. "All the important people except Suharto himself have come to Banda," said Oskar; meaning, they have come because of Des Alwi. And Oskar expects Des Alwi to bring Suharto.

But if Des Alwi is a king, it is not because that is his goal. His "komplek" is modest, overshadowed by his hotels which are built in Jakarta style with "Spanish" arches, as they are known in Jakarta. He thinks of his own position in terms of relationships with the influential people of Jakarta. We doubt that his Bandanese connections are of great use with them.

If Des Alwi is a king, it is because he has been made a king by the Orang Banda. Bandanese speak of him with pride; they point to what he owns, to his plans for Banda; they speak readily of working for him. It usually takes only two or three sentences in a conversation about Banda before "Des" emerges.

Des Alwi's elevation in the eyes of Orang Banda is tied to their expectation that he will fix things. In the smaller sense, this means giving them work, helping them when they are sick, and so on. There is also a more general sense in which they share his notion that something is inherently wrong in Banda, though they differ in naming the cause of the trouble. In the case of Oskar, an Orang Banda who is a man of all work for Des Alwi, it means that people in Banda, though not necessarily Bandanese, are jealous or envious, iri, and that they practice black magic. There are "people who like to make trouble for others [tukang membikin susah orang]," or those who in the Bandanese expression "menakal," cause trouble magically (for instance: "orang suka menakal orang"). For that reason, he told us, there are lots of dukun or curers in Banda. They can tell, by looking at a face, who is a troublemaker (orang jahat). They can tell if one has been affected by an orang jahat. They won't say who the orang jahat is; they could get into trouble themselves if they were accused of making such statements. Orang jahat seem like ordinary people, but they only talk that way ("cuma baik dimulut"); their actions are not good.

The orang jahat, according to Oskar, are mainly from the island of Ceram. They are iri or envious. "They see someone with money, they are envious." A certain xenophobia blends with envy over money, but such suspicion of outsiders is not always connected with wealth. Oskar said that Orang Banda do not like to marry Orang Butung (though there appears to be a lot of intermarriage). "The Orang Butung have two languages. We don't know if they are being contemptuous (menghina) or insulting (memaki)." If there are two ethnic groups on Banda it is possibly because one, the Orang Banda, suspect the intentions of the other and feel deprived of ever being certain of those intentions.

Suspicion of unreadable intentions leads to accusations of sorcery as well. Unreadable intentions are also what marked the cakalele until Wilky and Des Alwi and others established its true and stable sense. What is wrong in Banda is the continued presence of unreadable codes.

The case of sorcery is linked to money. People are envious when they see someone with money. It is not only Oskar who says this. Des Alwi's educated tour guide pointed out also that people are resentful (denki) of Des Alwi. Such people do not understand, he added. Without Des Alwi, Banda would be nothing. The tour guide did not mention sorcery. How- 
ever, like Oskar he sees money as the source of resentment. Oskar and the tour guide recognize how easy it is to feel envious of Des Alwi. They reject this feeling, however. They replace it with admiration and respect. It is through the generality of this replacement that Des Alwi becomes the king of Banda. If Orang Banda not only receive his help but have a right to ask for it, it is a right founded, thus, on a certain suppression. Others are envious; others turn to sorcery; they do not. "We," Orang Banda, are not wealthy; but "we" do not resent the wealth of Des Alwi. We therefore have a right to ask his help. This is the logic, rising entirely from below, that elevates Des Alwi to his kingship.

We were told about a man, a relative of Des Alwi, who hanged himself. The reason was, it was said politely, "possibly" because of "korupsi Des," meaning "corruption," betrayal of trust, of Des Allwi. In fact, the man added, such an act was completely uncalled for. It is true, he said, that Des Alwi can become angry. But then it passes and everything is all right. The trouble was that this man was "pemalu," a person easily affected with shame. He saw himself in the eyes of Des Alwi.

The Bandanese feeling of being seen in Des Alwi's eyes is connected to their sense of an inherent flaw in Banda. Their sense of being seen, of fearing Des's anger, of counting on his benevolence, rests on a sense of their own imperfection which they obscure from themselves. Bandanese, such as Oskar or the tourist guide, see Des Alwi as a possible object of envy. They refuse this feeling in themselves. They look to Des Alwi's benevolence to confirm their uncertain innocence. Like Des Alwi, they know something is wrong in Banda.

It does not matter much that what is felt to be wrong in Banda differs for the Orang Banda and for Des Alwi. For the Orang Banda it is envy, sorcery, and unintelligible language they project onto their neighbors. Suppression of envy establishes their relation to Des Alwi. For Des Alwi, what was wrong in Banda was the formerly unintelligible signs of the Bandanese. Des Alwi has a solution. He knows these signs are not necessarily uninterpretable at all and he proves it through the development of tourism.

Both sides begin with a notion of an unreadability within Bandanese social life. Des Alwi's solution is accepted by the Bandanese, though they do not seem to find the interpretation of the cakalele to be a matter of central importance. It is, however, important because it is the idiom within which Des Alwi formulates the unreadability of Bandanese society, makes it interpretable and presents it to the world. The result is tourism and with it the hoped for revival of Bandanese economy and society. There, both sides agree explicitly.

We visited the still unreconstructed home of Tjipto Mangoenkoesoemo. It is now inhabited by two families of school teachers. They knew of Tjipto but it was hard to say that they felt his traces. They could not say, for instance, which room Tjipto had used for a study, which for a bedroom, and so on. Across the street from the house there is a junior high school. One of the teachers, standing in the schoolyard, looking at the house, explained that the house used to belong to a doctor. Oskar interrupted to say, "Tjipto." It seemed to us that the teacher did not know who Tjipto was. The teacher explained to us that the house had been built by the Dutch; that the Dutch were the first settlers of Banda and were there for a long time, centuries in fact. The Portuguese came after them; they could not make much of an impression; the Dutch had built everything already. In any case, the Portuguese were not in Banda long, having been chased out by the Japanese. ${ }^{4}$ He referred to the time before the

4 During our short stay in Banda we came across three incidents in which "Portuguese" was misused. Once the historical sequence in which Portuguese preceded Dutch was reversed, as we have just related; the second time, 
Japanese occupation as "ancient times" ("zaman purbakala"). He concluded by saying that they were greatly indebted to tourists because, "thanks to tourists, history was dug out [sebab dengan turis, sejarah digali]."

The notion that history is there to be dug out prevails with Des Alwi also. When we asked him what proof there was that a Japanese "samurai" killed the Bandanese nobility in such a cruel and horrifying way, he told us that he came across the books and documents in Holland which tell of the incident in great detail. He spoke calmly in a tone that was meant to reassure. We felt he was certain that the complete history of Banda could be found in Holland; it needed only to be dug out. ${ }^{5}$

Historical "discovery" is closely tied to tourism in other places as well. Tourism frequently having an international character, it is not surprising to find a single logic. In Japan the prevailing slogan is "Discover Japan," always in English, never in Japanese, though it is directed at Japanese. And indeed the discovery of a place, valuable for its views and its fishing, and the discovery of a place valuable for its past are central elements of tourism. Tourists are presumed to want to spend time and money to forget their own daily lives. Thus places which evoke sentimental and nostalgic feelings need also to be places which do not seriously involve them. Tourists are like readers of Japanese papers and magazines which are replete with reports of archaeological discoveries found in such and such a region, often featured on the front page. The producers and consumers of such reports are affected by them only sentimentally. In Banda we see how a feeling of discomfort is assuaged through the harmlessness of the touristic.

The phrase "thanks to tourists, history was dug out" means, in this logic, that surely there is something that existed before that we have forgotten. It is only necessary to dig it out to remember it, digging taking place with assured success either in the ground or in the archives. One digs not to find something in particular, but because one knows something of a character entirely unspecified is there.

The teacher who told us about the Portuguese and the Dutch is an Orang Banda, but as a teacher he, like Des Alwi, the Jakartan, has a nationalist perspective. he thinks of history in terms of ages. That he reverses the sequence of Dutch and Portuguese is not necessarily important. What matters, at least to us, is that for him history is something presented to tourists. With tourists, history (or "ancient times") is dug out. Tourists call it forth, as when we asked about Tjipto Mangoenkoesoemo's house. He had to respond. Otherwise he would not be concerned about it. He learns history to tell it to tourists. It is the history of his own place, his own history. But it is learned to tell to certain others. The result of which is that tourists not only furnish the motivation to study history, they become its repository. He himself apparently forgets it when he tells it, as the reversal of ages indicates. "History," here, is that which belongs to one but to which one has paid no heed. The tourist is the

\footnotetext{
"Dutch" was used to describe a Portuguese name, and the third time a Dutch house was labeled "Portuguese." Its use marks a rift between linguistic terms and their anchoring in the historical world, as though the first colonialism was the beginning of a small delirium.

${ }^{5}$ Language appropriate to tourists of course appears on souvenirs. T-shirts, made in Bandung, West Java, bear slogans, in English, such as "Bandaneira, the island of nutmeg," "I am a nutmeg from Banda," "V.O.C 16021799," the initials standing for the Dutch East India Company. We have never seen this term on souvenirs elsewhere. If the V.O.C. has long disappeared, if the days of Banda's command of world nutmeg supply are long gone, if Banda, the place, is no longer known to the world, nonetheless, the written signifiers remain, indicating that there really is something to dig up.
} 
figure in whose name one notices this irritation and simultaneously passes it on. The reactions of the Orang Banda presently living on Banda are not greatly different from Des Alwi's.

Living amongst centuries of relics there is perhaps naturally (perhaps not too) some notion of them that is, however, short of the interpretative; short of the laying bare of secrets. Oskar Sahupalla was born in Banda. By descent he is Ambonese and Chinese. He is a man of all work for Des Alwi and also picks up jobs from tourists, showing them around the islands. He had a grade school education under the Dutch. He was a sailor on interisland shipping around New Guinea (now called Irian); he returned to the Moluccas when conflict between the Dutch and the Republic broke out over West Irian. He knows the local Banda scene; where the underground passage between the two old forts is; that the Dutch used cubicles inside the fort to hold prisoners and the upper stories for defense; that an impressive-looking building was once the office of the Dutch Assistant Resident, then was used as the camat's office (camat was the Indonesian term for a government official) until a new one was built. And so on. He earns money by relating some of this information, but he learned what he knew simply by growing up in Banda and he knows more than he needs to know. His knowledge is recalling what he heard as a youth. It is fragmentary in the sense that there is no interpretation that leads back to an overarching explanation. Unlike Wilky, for instance, he does not speak of Dutch intentions that explain why certain things are as they are. Rather he places things by era ("jaman"); "the Portuguese era," "the Dutch era." This sequence is not a chronology. He thinks that his aunt's house, a nineteenth-century Dutch mansion, dates from "the Portuguese era." (It seems that Bandanese frequently stumble on the word "Portuguese"; it appears to mean "I'm not sure I know" or "I'm not sure I'm knowable.") The effect of thinking in achronological sequences is the flattening out of events. One does not influence the next; rather, eras are mere classificatory devices or means of identification of objects. ${ }^{6}$ By the same kind of logic, Oskar, who of course knows about the cakalele, does not allow it to dominate his thinking which acknowledges no general schema.

Oskar's knowledge is not rote; it is a function of his intelligence in working out a certain sort of narrative. Nor was this done with the aim of sale to tourists; the process was accomplished before their arrival. It is, rather, part of the manufacture of the ideology of the Orang Banda.

Oskar's history is the history of other people. "The Dutch did this; they built that"; "the Portuguese built that"; are typical formulations. There are no heroes in his stories. Even speaking about the cakalele, which in any case does not assume much prominence in his conversation, he does not stress resistance to the Dutch. Heroes emerge in Banda only with interpretation; interpretation becomes usable with nationalism and tourism.

For Oskar, history is what other people did and what, at most, Bandanese avoided. Thus Bandanese of a certain age remember the American bombing of Banda during World War II. We heard the story from several people. Each time it centered on the digging of holes (lobang) in which to hide. Oskar's story is that, when the bomber came, he, still a boy at the time, scurried into a hole under the roots of a tree. This was his lobang; other people had

\footnotetext{
${ }^{6}$ For instance, one of Des Alwi's hotels has a small collection of Time magazines dating from the early $1980 \mathrm{~s}$. These are offered to guests. During our stay there was also a supply of Jakartan newspapers from the previous year. The manager of the hotel applied himself, in a way Somerset Maugham would have approved, to one of these each afternoon. Such writing, in his view, does not expire; events are dislocated from their temporal settings.
} 
their own. He knows this. He said: "At the time, people here dug holes. Had they been hit [by a bomb] they would all have been killed. [Pada waktu itu, orang disini gali lobang. Pada waktu dibom, kalau kena, habis semua.]" Then he laughed. His laugh was a form of pleasure. He delighted in the foolishness of adults. He himself, at the time, imitated adults; they dug holes; he dug a hole. But holes would not have helped. His laugh makes adult activities childish. He avoids adult seriousness and his telling of the story makes it un-serious.

Oskar used that laugh frequently in telling us about Banda's history. But perhaps the best example of it was when he explained how the turtles in Des Alwi's pond eat the fish. "They swim up behind very, very slowly. Then they snap very quickly." He imitated the turtle; then he laughed. In a certain way he placed himself in the position of the turtle. But when he laughed he rejected this identification, dissolving it into the pleasure of telling the anecdote. The act had no consequences; no one, Des Alwi, his guide, the Orang Butung, perhaps even the poor fish, need be upset. This was no different in tonality than his telling of how the Dutch kept prisoners in the cells of Fort Belgica. His identification was with the Dutch, as it was with whomever or whatever he spoke about. But it was an identification that lasted only as long as the anecdote, the result of a curiosity free to find its way anywhere, on the condition that there be no consequences.

Oskar's attitude characterizes others' stories of aspects of the bombing. The American bomb killed many people who were about to board a ship. Three people told us of the carnage. Each used the same gestures: a finger drawn along a line separating neck from shoulders to show a head had been cut off; the same finger drawn across the opposite arm below the elbow showing an arm lost. This is the story of people killed and dismembered described on the teller's own body. It is the same insistence on dismemberment that one finds in Des Alwi's description of the deaths of the Bandanese nobles. But in this case, the pleasure in description, in its economy perhaps, dissolves the need to share the feelings of the victims. The event is drained of seriousness, that is, of consequences, by the manner of its telling as, in a different way, is also the case for Des Alwi. By contrast, sorcery was always spoken in the register of seriousness; its effects are thought to be inescapable.

This is history as the avoidance of effects. It is a history in which differences between Americans, Japanese, and Dutch disappear. What is important is what whoever the colonizers, the Orang Banda who spoke to us avoided being damaged by them. The sense of the stories is, "history does not affect me, therefore I can be myself." History does not choose me. Oskar, or whoever tells the story, reassures himself that his name, his identity, does not bring about his death.

The disconnection of Orang Banda from their history is reflected in the unusual circumstance that, according to Oskar, none of the old houses are haunted. Considering the active belief in sorcery, considering Oskar's openness on that subject and on that of the haunted graves, we expected to be told about haunted houses. That they seem not to exist reflects the lack of aura of these buildings for Bandanese, or at least for Oskar. But how close the buildings come to be being haunted is revealed in another story of Oskar's. In an old Dutch building near the magnificent Assistant Resident's mansion, a Dutchman hanged himself. Before he did so, he scratched a message on the window pane. the message is said still to be there. Oskar, however, does not know what it says. It is hard to find and hard to read. Messages from the past, practically invisible and in any case hard to decipher, suspended from the time of the author's death, waiting only for someone to come upon them to reach, acci- 
dentally, an audience wholly different from their intended address; such messages are almost ghosts.

History is restored for some on Banda, perhaps particularly school children, through tourism and, closely connected with that, national recognition. Certain buildings, notably the house occupied by Hatta, have been renovated and now bear a plaque saying, in the case of the house of Indonesia's first Vice President:

\section{DEPARTMENT OF EDUCATION AND CULTURE DISTRICT OFFICE OF MOLUKU Restoration House of Exile of Bung Hatta \\ On Banda Neira}

Restoration begun in the year 1960

Restoration completed in the year 1985

Made official the 20th of October, 1985

By

Director General of Culture

Department of Education and Culture

Republic of Indonesia

This plaque with its signature seems to make the house recognizable. As we have mentioned, the school teacher, standing in front of Tjipto Mangunkoesoemo's house which lacked such a plaque, seemed not to know to whom it belonged. Des Alwi himself, at great expense, has restored Sutan Sjahrir's house. However it had not yet been made official and so did not bear a plaque. School children, asked where it was, were not sure, though, in fact, they eventually pointed to the correct building.

School children and their teachers belong to the realm of the official. Their answers to tourists' questions come from knowledge they have gained in school. When we asked these children something in Indonesian they answered in a stiff and formal manner, quite in contrast to the fluent chatter that went on between themselves. They spoke as though they were reading aloud from their school books, yet we merely asked for directions. They knew that the appropriate language for tourists, as opposed to the appropriate language for adult Bandanese, was the language of the text book. Children may know about Banda from their experience, as Oskar knows, but they do not draw on such knowledge. For them it is not part of the discourse which pertains between the historical Banda and tourists, figures whose presence proves the transmissibility of such knowledge.

Indonesian official knowledge, knowledge controlled by the state, depends on a notion of perfect transmissibility. Such language is always assumed to exist elsewhere-if not in Jakarta, then in Holland. Always, that is, outside the grasp of most people but not, as in other places, because of their illiteracy. The wish for perfect transmissibility is the wish that the local condition of language, that it is outside the control of its speakers, at critical moments unintelligible, used by those possessed by envy and possessing magic, be rectified.

A language that is always intelligible precludes it being the local language which is necessarily at moments at odds with its speakers. It is at this point that the dream of perfect transmission becomes available to become official language. Perfectly transmissible language is necessarily in the hands of others. It is the language of government officials in Jakarta, of tourists; always the language of those who are from somewhere else. 
The speakers of such a language are presumed to know. If they do not themselves know, still, seeing them, one remembers that there is something to remember: "Thanks to tourists, history is dug up." In the National Library in Jakarta, a vast repository of national history, it is common to have Indonesians say to one that all the documents of their past are now in Holland. If others speak the world language, the language presumed to be perfectly transmissible, they could have received all the messages of history. The secret of the cakalele was buried in Holland. This is merely another version of the urge, once the secret of the cakalele was dug out, to send it again into the world arena, cleansed of the complications, even the possible ghosts, that might arise from whatever is wrong in Banda.

Before the code of the cakalele was deciphered the story of the deaths of the Bandanese nobility was unknown. Until Wilky related the names to the historical event of murder the names were repeated without anyone knowing even that they were names. It was the story of their deaths that made the names known. What is sensed to be wrong in Banda today is also a question of relating names to death. Oscar and others believe that it is the envious who apply to sorcerers. The envious, like sorcerers, are unintelligible. One cannot say from their faces who they are; sometimes one cannot understand their words. But when one knows them one sees that they are murderers. Stories of murder here, as in the cakalele, furnish intention, hence intelligibility. Death assuages the ravages of the lack of referents.

Wilky Rinpassa insists that he is, or he should be, readable. The same insistence is behind the contract that makes Des Alwi king, or "president," of Banda. To insist that "I am not envious" is to say that I am who I claim to be. I have no hidden intentions. I am not like the envious who could murder. I am not like the envious who are not identifiable. I am readable. They are not. My name says what I am; their names reveal nothing. I, however, am alive. My attachment to my name, my transparency to others, proves it. This is the assumption that leads to the control of the envious, to the founding of a social order; it leads, in fact, to a kingdom carved out of a republic. And from there it leads, in the present era, to proof of readability, translating itself into a believed-to-be universal language which obscures the unintelligible and manufactures invincible kitsch, to be disposed of with tourists. 